DOI: https://doi.org/10.31933/dijemss.v2i3 Received: $30^{\text {th }}$ June 2020, Revised: $15^{\text {th }}$ December 2020, Publish: $3^{\text {nd }}$ March 2021

\begin{tabular}{|c|c|c|}
\hline PUNAISHER & $\begin{array}{l}\text { DIJEMSS } \\
\text { DINASTI INTERNATIONAL JOURNAL } \\
\text { OF EDUCATION MANAGEMENT AND } \\
\text { SOCIAL SCIENCE }\end{array}$ & $\begin{array}{r}\text { https:I/dinastipub.org/DIJEMSS } \\
\text { editor@dinastipub.org } \\
08117401455 @\end{array}$ \\
\hline
\end{tabular}

\title{
EFFECT OF SHARING FUNDS (DBH) FOR REGIONAL BUDGET INCOME (APBD) PRODUCING REGIONS (STUDIES IN INDONESIA UPSTREAM OIL AND GAS INDUSTRY)
}

\author{
Kasman Arifin ${ }^{1}$, Dina Hidayat ${ }^{2}$, Halimahtussakdiah ${ }^{3}$ \\ ${ }^{1)}$ Universitas Islam Riau, Pekanbaru, Indonesia, kasmanarifin@eco.uir.ac.id \\ ${ }^{2)}$ Universitas Islam Riau, Pekanbaru, Indonesia, dinahidayat@eco.uir.ac.id \\ 3) Universitas Islam Riau, Pekanbaru, Indonesia
}

Corresponding author: Dina Hidayat ${ }^{2}$

\begin{abstract}
Revenue-sharing is an oil-producing region allocation is used as the working area of mining. Along with fiscal decentralization and greater regional autonomy lately, the revenue sharing should be used in order to increase the prosperity of oil and gas producing regions through APBD revenue. This study aims to determine the effect of profit sharing funds in the upstream oil and gas industry in Indonesia on the regional budget. This research is associative explanative. Data collected through interviews, questionnaires, observation and literature study. Data were analyzed descriptively, tested assumptions, estimated through path coefficients and confirmatory factor analysis. After that the model is interpreted and modified. The results show that the effect of revenue sharing funds on the regional budget is significant. The greater the revenue sharing funds, the greater the APBD producing regions.
\end{abstract}

Keywords: Revenue Sharing Funds (DBH), Regional Budget and Revenue, Production Sharing Contract, Oil \& Gas Industry.

\section{INTRODUCTION}

In addition to contributing revenues to the state, the oil and gas industry is a significant contributor to PAD for oil and gas producing regions, and is an opening frontier region. Oil and gas exploration is mostly done in remote areas and once oil and gas is discovered, the area develops. (Partowidagdo, W., 2002; 3).

Law Number 33 of 2004 concerning central and regional financial balances, has set the amount of allocation for each producing region as the following:

Table 1 Percentage of Revenue Sharing

\begin{tabular}{|c|c|c|c|c|c|c|c|c|c|}
\hline \multirow[b]{2}{*}{ Number } & \multirow[b]{2}{*}{ Type of Income } & \multicolumn{3}{|c|}{$\begin{array}{c}\text { Before Regulations } \\
\text { of PKPD }\end{array}$} & \multicolumn{4}{|c|}{ After Regulations of PKPD } & \multirow{2}{*}{$\begin{array}{c}\text { Regulati } \\
\text { ons } \\
\text { Special } \\
\text { Autono } \\
\text { my Act }\end{array}$} \\
\hline & & $\begin{array}{c}\text { Centr } \\
\text { al }\end{array}$ & $\begin{array}{c}\text { Pro } \\
\text { p }\end{array}$ & $\begin{array}{c}\text { Distri } \\
\text { ct }\end{array}$ & $\begin{array}{c}\text { Centr } \\
\text { al }\end{array}$ & $\begin{array}{c}\text { Pro } \\
\text { p }\end{array}$ & $\begin{array}{c}\text { Distri } \\
\text { ct }\end{array}$ & Other & \\
\hline
\end{tabular}




\begin{tabular}{|c|c|c|c|c|c|c|c|c|c|}
\hline & & & & & & & & & $\begin{array}{c}\text { (NAD \& } \\
\text { Papua) }\end{array}$ \\
\hline 1 & PBB & 10 & 16.3 & 68.8 & & 16.2 & $\begin{array}{c}64.8(+ \\
)\end{array}$ & + & 90 \\
\hline 2 & ВРНТВ & 20 & 16 & 64 & & 16 & $64(+)$ & + & 80 \\
\hline 3 & $\mathrm{IHH}$ & 55 & 30 & 15 & 20 & 16 & 64 & & 80 \\
\hline 4 & PSDH & 55 & 30 & 15 & 20 & 16 & 32 & 32 & 80 \\
\hline 5 & Landrent & 20 & 16 & 64 & 20 & 16 & 64 & & 80 \\
\hline 6 & Royalty PU & 20 & 16 & 64 & 20 & 16 & 32 & 32 & 80 \\
\hline 7 & Fisheries & 100 & & & 20 & & & 80 & 80 \\
\hline 8 & Oil & 100 & & & 85 & 3 & 6 & 6 & 70 \\
\hline 9 & Natural Gas & 100 & & & 70 & 6 & 12 & 12 & 70 \\
\hline 10 & Reforestation Fund & 100 & & & 60 & & 40 & & 40 \\
\hline 11 & $\mathrm{PPh}$ & 100 & & & 80 & 8 & 12 & & 20 \\
\hline
\end{tabular}

Source: Processed from Law Number.33 of 2004

The division of regions based on the Law on regional autonomy can be seen in Table 2 as follows:

Table 2. Regional Divisions based on OTDA

\begin{tabular}{|l|r|r|}
\hline \multicolumn{3}{|c|}{ SIMULATION } \\
\hline \multicolumn{3}{|c|}{ DISTRIBUTION REGIONAL BASED ON OTDA } \\
(In billions of rupiah) \\
\hline Fund balance & APBN 20X2 & \multicolumn{1}{|c|}{ APBX3 } \\
Profit sharing funds & $\mathbf{9 4 , 5 3 1 . 7 0}$ & $\mathbf{1 0 3 , 5 9 1 . 4 0}$ \\
Tax & $\mathbf{2 4 , 6 0 0 . 3 0}$ & $\mathbf{2 5 , 8 5 3 . 1 0}$ \\
PPh Individual & $11,945.50$ & $14,802.60$ \\
PBB & $4,071.00$ & $5,250.10$ \\
BPHTB & $5,669.50$ & $7,141.80$ \\
Natural & $2,205.00$ & $2,410.70$ \\
Resources petroleum & $12,654.80$ & $11,050.50$ \\
Natural gas & $5,784.60$ & $4,724.00$ \\
General Mining & $4,778.60$ & $4,606.20$ \\
Forestry & $1,072.00$ & $1,186.10$ \\
Fishery & 786.20 & 300.80 \\
General Allocation Fund & 233.40 & 233.40 \\
The Province & $\mathbf{6 9 , 1 1 4 . 1 0}$ & $\mathbf{7 5 , 4 1 4 . 3 0}$ \\
Districts & $6,911.44$ & $7,541.40$ \\
Special Allocation Funds & $62,202.70$ & $67,872.90$ \\
Reforestation Fund & $\mathbf{8 1 7 . 3 0}$ & $\mathbf{2 , 3 2 4 . 0 0}$ \\
Non-Reforestation Funds & 817.30 & 324.00 \\
Special Autonomy and & - & $2,000.00$ \\
Funds Balancing & $\mathbf{3 , 4 3 7 . 0 0}$ & $\mathbf{9 , 6 2 4 . 9 0}$ \\
Special Autonomy Fund & $1,382.30$ & $1,508.30$ \\
Balancing Fund & $2,054.70$ & $8,116.60$ \\
\hline Amount & $97,968.70$ & $113,216.30$ \\
\hline Sources: Processed Data from the OTDA & $\mathbf{a n d}$ \\
\hline
\end{tabular}

Sources: Processed Data from the OTDA and KONTAN Law No. 49

The table above is a revenue sharing scenario to reduce conflicts between the center and the regions so it is necessary to: 1) provide an explanation and understanding of the oil and gas potentials that can be managed by the local government, 2) absorb various problems in oil and gas producing regions. 3) enlighten the regions so they can understand and understand the potential of oil and gas in their respective regions. 4) provide an understanding of the profit sharing calculation system that is now considered crucial. 5) so 
that the region understands the oil and gas industry as a whole in order to increase revenue sharing funds. (KONTAN No. 49, 2002).

Crucial to the period of regional autonomy are: 1) profit sharing calculation system, 2) field reserves and 3) how the existing oil and gas potential can be managed well.

This paper aims to determine whether the revenue sharing funds obtained by oil and gas producing regions have a significant influence on the Regional Revenue and Expenditure Budget (APBD). The results of the study are expected to contribute to policy makers related to the upstream oil and gas industry.

\section{LITERATURE REVIEW \\ Indonesian Upstream Oil \& Gas Industry}

Considering the strategic role of oil and gas in national development, the government on August 20, 1968 decided that oil and gas exploitation must be carried out by a state company.

The company appointed to carry out the government policy is the National Oil and Gas Mining Company (PN Pertamina).

According to Law Number 8 of 1971, Pertamina is responsible for managing Indonesia's oil and gas resources in all related aspects such as exploration, exploitation, production, processing, transportation and sales of oil and gas.

Industry in general is a certain business group that has the same techniques and methods in generating profits. Petroleum (English: petroleum, from Latin petrus-coral and petroleum-oil), also known as black gold, is the result of a natural process in the form of hydrocarbons under atmospheric pressure and temperature conditions in the form of a liquid or solid phase, including asphalt, mineral wax or ozokerite, and bitumen obtained from the process of mining Oil and Gas (Act Number 22 of 2001).

The oil and gas industry is different from other industries in general, both in terms of characteristics, the regulations that govern it and the accounting treatment therein. The oil and gas industry has special regulations created to regulate the practices and activities of the perpetrators. In Indonesia, this regulation is stipulated in, among others, Law Number 22 of 2001 concerning oil and gas explaining the definition, activities and procedures for oil and gas industry practices in Indonesia, and most recently PP Number 79 of 2010 which contains additional regulations regarding the cost recovery component in the production sharing contract in the oil and gas industry. It was not previously regulated in Law Number 22 of 2001 .

\section{Production Sharing Contract}

Since the enactment of Law Number 8 of 1971, a new era of petroleum and natural gas management has become known as a new form of cooperation, where Pertamina can work with other parties, while the forms of cooperation include:

1) Contract of work, in this contract the distribution is based on profits, while management and ownership of assets are in the hands of the contractor. 
2) Production sharing, management and asset ownership contracts are in the hands of Pertamina, which is divided into production after deducting operating costs.

After Law Number 22/2001, all arrangements and forms of agreements in the upstream oil and gas industry have changed drastically, Pertamina's authority has been cut. The authority in the upstream sector is handed over to the Oil and Gas Implementing Agency (BP MIGAS) while in the downstream is handed over to the Regulatory Agency (Legal Review No. 35 / TH III August 2005, 11).

The soul of the provisions of the Articles of Production Sharing Contract / Cooperation Contract can be seen from the scope of the existing contract, consisting of five main paragraphs, namely:

1. Paragraph 1 This contract is a production sharing contract.

2. Paragraph 2 SKK MIGAS will have rights and responsibilities for operations management, and the contractor is responsible for oil and gas operations.

3. Paragraph 3 The contractor provides all financing and technical assistance.

4. Paragraph 4 The contractor bears the risk of operating costs and interest costs incurred to finance operations.

5. Paragraph 5 Throughout the agreement in the contract, the total production is divided into sequences.

Regarding profit sharing in the PSC (Production Sharing Contract) it is a matter that is always being negotiated. For Indonesia, it still adheres to the law, that in making contracts, it must always prioritize the interests of the nation. (Ernst G. Tehuteru, Legal Review No. 35 / TH III August 2005, 32).

Looking at the development of the contract of work model as well as the production sharing contract or cooperation contract, the dominance of foreign parties or the influence of investors is very thick, even for the first generation contract the concept is made by the company's legal experts concerned.

In order to make this cooperation contract attractive to foreign investors, various ways are carried out by the government by providing incentives. So that this incentive does not reduce and guarantee government revenue, the contractual obligation includes the contractor's obligation to deliver his first production, known as First Tranch Petroleum (FTP) and so that the supply of oil and gas for domestic needs is guaranteed, a regulation known as the Domestic Market Obligation .

In the upstream oil and gas industry, this fiscal system is more emphasized and becomes an inseparable part of the contract as stated by Johnston, D. (2003: 13) It is a clear tendency (obvious) in the 1980s and 1990s. Many countries are developing fiscal systems for oil and gas by taking the option to use Production Sharing Contracts (PSCs). What is certain is that the lower limit is the same as the royalty / tax system, depending on the aggregate level of royalties, taxes and business continuity. Political and philosophical aspects are included, however, profits will always be the main choice of Production Sharing Contracts (PSCs). 
The government sees the use of the fiscal system in a macroeconomic emphasis in which the profits from the upstream oil and gas industry are immediately recognized as state revenue, while the company sees this fiscal system from the opportunities given to companies in order to generate maximum profits.

\section{Cost Recovery}

Operating cost recovery is introduced in a Production Sharing Contract (PSC) since the first generation towards the mid 1960. Until now, the implementation, application and method of calculating the cost recovery has reached the third generation and will still develop according to the conditions.

Cost recovery is the return of costs incurred by the contractor for the purposes of exploration, development and operating costs beyond gross income. Most production sharing contracts have limits on the amount of contractor income recognized to get a refund but not all costs can be requested for repayment, such as last year's funding and refunded in the event year. The limitation of cost recovery or the limit of the refund limit as commonly known ranges from 30\% - 60\%. (Johnston, D., 1996: 56)

In petroleum operations generally there are cost controllable costs in administering administration, while uncontrollable costs include efforts to find additional reserves through exploration and development activities and the addition of production facilities.

Cost recovery in the calculation of equity to be split between the government and the contractor has a very significant effect. The greater the refund of costs that can be requested by the contractor back to the government, the smaller the state revenue.

Te cost recovery path in the upstream oil and gas industry in Indonesia can be described as follows:

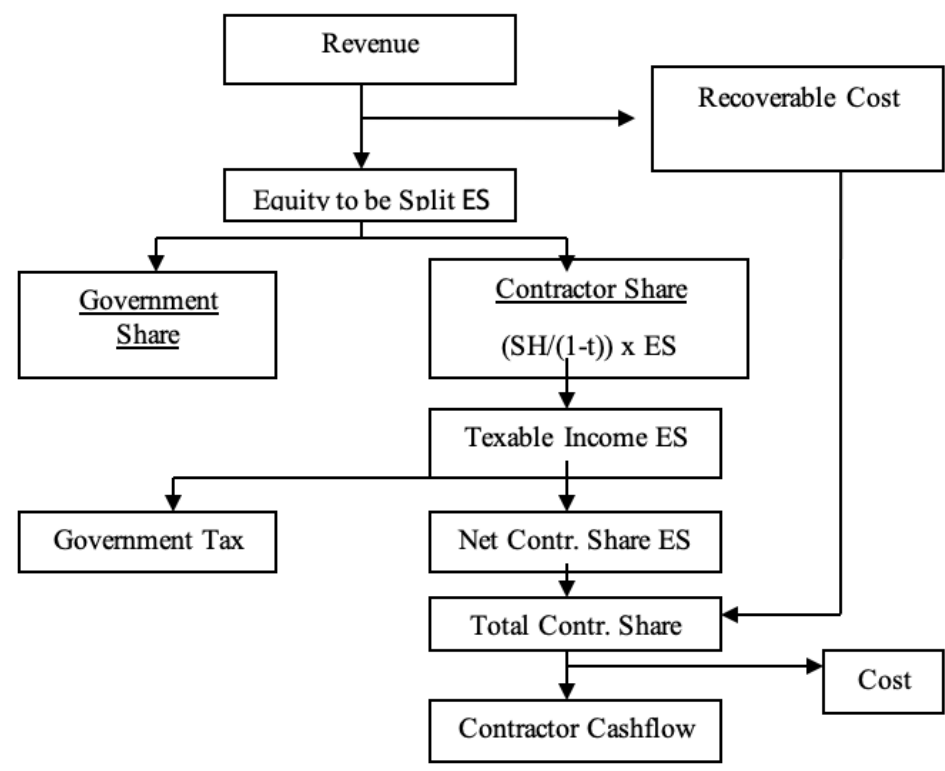

Figure 2 Flow Cost Recovery in Product Sharing Contract 


\section{Previous Research}

Based on the research, it turns out that the production sharing contract still provides benefits above the fairness of the contractor and the way to calculate the cost. It is still not in accordance with general accounting principles. (Sutadi, 1999).

Sitorus, B ,. (2001: 15) says that the return into place costs is a return of costs (sunk cost capital \& operating cost) made in kind from the results of production of the mining work area (WKP) after the activity is completed and the assets have been utilized according to their functions.

Rezky Sri Wibowo (2005), stated that, extractive economy also gives a significant contribution to Indonesia's foreign exchange income or reserves (exports), especially in the early times of the development process of the economy. This research is trying to prove that the extractive sector of the economy, government or private, is very closed, especially when it comes to income gained from PSC (Production Sharing Contracts). The origins of oil and gas income realization numbers are barely traceable in the national budget (APBN) documents. If one intends to trace the details of income the calculation is then said to be connected to "cost recovery".

Daniel Johnston, (2004), science of petroleum engineering is always one step ahead in analysis and design compared to other sciences. One of its key aspects that is never left out is its standard terminology with the fiscal analysis system. Sometimes people use the term "Shared Fund" to identify income components not profit.

The government often loses information during a period of exploration and the focus of calculation then shifts to Internal Rate of Return. From all the problems found in the production sharing contracts for many countries, the most staggering problem lies in the articles of the contracts, and until a contract is agreed upon by all parties, the contract must be first reviewed by an accountant or a group of accountants or a consultant to protect the economic interests of the country whose oil and gas belongs to.

\section{RESEARCH METHODS}

This research is associative explanatory. The hypothesis proposed in this study is: Fund for Sharing! The results of Indonesia's upstream oil and gas industry affect the regional budget.

Respondents' answers are categorized based on a Likert scale where each answer has a gradation from very positive (agree) to very negative (disagree) ranging from a score of 1 for very no effect to a score of 5 for very influential. Furthermore, to categorize the average response of respondents, an interval scale is calculated which is calculated from the highest score minus the lowest score divided by five categories of answers, then obtained an interval for each category of 0.8

Description of the conditions of research respondents can be seen in the results of descriptive analysis in the form of frequency tables and descriptive statistics between others are minimum values, maximum values, average values and standard deviations. 
The population in this study is the Oil and Gas management agency abbreviated as BPMIGAS which oversees 95 Cooperation Contract Contractors (KKKS), 18 JOB / JOA and 5 TACs in which as many as 44 KKKS have produced

The population of this study are employees who work in KKKS and BP MIGAS at levels of managers, professionals and researchers from tertiary institutions, with the composition as shown in Table 3 below:

Table 3 Composition of the Study Population

\begin{tabular}{|l|c|c|c|c|c|}
\hline \multirow{2}{*}{ Population } & Amoun & \multicolumn{4}{|c|}{ Years of Service } \\
\cline { 3 - 6 } & $\mathbf{t}$ & $\mathbf{2 0}$ & $\mathbf{1 5 - 2 0}$ & $\mathbf{1 0}-\mathbf{1 5}$ & $\mathbf{5 - 1 0}$ \\
\hline Level Manajer & 62 & 31 & 17 & 11 & 3 \\
\hline Professional & 51 & 21 & 6 & 16 & 8 \\
\hline College & 18 & 0 & 8 & 10 & 0 \\
\hline Total Population & 131 & 52 & 31 & 37 & 11 \\
\hline
\end{tabular}

The sample is determined through 3 stages, namely (1) cluster sampling, (2) quota sampling, and (3) random sampling.

The cooperation contract contractors that became the sampling area of this study all numbered 44 companies with three working areas (regions I, II and III)

Data were collected by means of observation, interviews, documentation and Likert scale questionnaires. Structural Equation Modeling (SEM) is used as a research model. Estimating the effect of variables on other variables using the path coefficient after data analysis and assumption testing simultaneously and simultaneously.

To test the predictive power of each indicator and hypothesis used a CR (critical ratio) benchmark value on the regression weight with a minimum value of 2 (two) in absolute terms, and a value of $\mathrm{p}<0.05$. Furthermore, to examine the variables that define a factor that cannot be measured directly, confirmatory factor analysis is used, where this analysis is to give meaning to the latent variable that is confirmed. After that, interpretation and modification of the model.

\section{INTERPRETATION OF RESEARCH RESULTS Descriptive Analysis Regional Budget of Revenue and Expenditure (Y)}

Indicators of Regional Budget of Revenue and Expenditure (Yl) are regional own revenue (Yl. 1), balancing funds (Y12.), Regional loans (Y1. 3). The results of the tabulation of data from respondents obtained the percentage of respondents' answers to the variable Regional Budget Revenues and Expenditures that can be seen in Table 4.

Table 4 Percentage of Respondents' Answers for the APBD Variable Factor

\begin{tabular}{|c|c|c|c|}
\hline Score & Y1.1 & Y1.2 & Y1.3 \\
\hline 1 & 0.00 & 0.00 & 0.00 \\
\hline 2 & 0.00 & 0.80 & 1.50 \\
\hline 3 & 8.40 & 13.70 & 19.10 \\
\hline 4 & 61.80 & 58.00 & 67.20 \\
\hline 5 & 29.80 & 27.50 & 12.20 \\
\hline Total & 100.00 & 100.00 & 100.00 \\
\hline
\end{tabular}


Descriptive analysis of respondents' answers to the regional income and expenditure budget variable (Y1) produces the average value and standard deviation for each of the region's original revenues (Yl.1), balancing funds (Yl. 2), and regional loans ( Yl. 3), which can be seen in Table 5 .

Table 5 Mean Values and Standard Deviations of Each Indicator from APBD Factor Variables

\begin{tabular}{|c|c|c|}
\hline Indicator & Average & Standard Deviation \\
\hline Y.1.1 & 4.21 & 0.583 \\
\hline Y.1.2 & 4.12 & 0.657 \\
\hline Y.1.3 & 3.90 & 0.606 \\
\hline
\end{tabular}

Based on the table it can be said that basically respondents have a good perception of the APBD. In Table 4 it can be seen that more and 95\% of respondents answered score 3, score 4 and score 5 . In Table 5 it can be seen that the average value of each indicator and APBD factor variable is in the range of 4.

\section{Profit Sharing Funds (Y2)}

Oil and gas revenue-sharing funds (Y.2) that have been deducted in such a way are based on the total volume of the structure multiplied by the total production of the Mining Work Area (WKP). constitutes revenue of a region and is one of the components and APBD of profit sharing fund (Y.2) indicators are oil and gas production (Y.2.1), oil and gas working area (Y.2.2.), oil and gas prices (Y.2.3).

The results of the tabulation of the data and the respondents obtained the percentage of respondents' answers to the profit sharing fund variable which can be seen in the following Table 6:

Table 6 Percentage of Respondents' Answers for Revenue Sharing Factor Variables

\begin{tabular}{|c|c|c|c|}
\hline Score & Y.2.1 & Y.2.2 & Y.2.3 \\
\hline 1 & 0.00 & 0.00 & 0.00 \\
\hline 2 & 0.80 & 1.50 & 1.50 \\
\hline 3 & 14.50 & 14.50 & 16.80 \\
\hline 4 & 50.30 & 70.30 & 54.20 \\
\hline 5 & 24.40 & 13.70 & 27.50 \\
\hline Total & 100.00 & 100.00 & 100.00 \\
\hline \multicolumn{4}{|c}{ Source: Processed Products } \\
\hline
\end{tabular}

Descriptive analysis of respondents' answers to the profit sharing fund variable (Y.2) produces the average values and standard deviations for each production indicator (Y.2.1), work area indicator (Y.2.2), and price indicator (Y .2.3), can be seen in the following Table 7:

Table 7 Average Values and Standard Deviations of Each Indicator from Variable Factors Funds for Results

\begin{tabular}{|c|c|c|}
\hline Indicator & Average & Standard Deviation \\
\hline Y.2.1 & 4.08 & 0.645 \\
\hline Y.2.2 & 3.96 & 0.587 \\
\hline Y.2.3 & 4.08 & 0.708 \\
\hline
\end{tabular}

Source: Processed Results 
Based on the table it can be said that basically the respondent has a good perception of revenue sharing. In Table 6 it can be seen that more than 95\% of respondents answered score 3 , score 4 and score 5 . In Table 7 it appears that the average value of each indicator of the variable profit sharing factor is in the range of 4.

\section{Test Validity}

Table 8 Test Results of Validity And Reliability of Research Instruments For The APBD Factor Variable

\begin{tabular}{|c|c|c|c|c|c|}
\hline \multirow{2}{*}{ Indicator } & \multicolumn{4}{|c|}{ Validity Test } & \multirow{2}{*}{$\begin{array}{c}\text { Constract } \\
\text { Reliability } \\
\left(\rho_{\Pi}\right) \\
\end{array}$} \\
\hline & $\begin{array}{c}\text { Estimat } \\
\text { e }\end{array}$ & $\mathbf{P}$ & Information & GFI & \\
\hline Y1.1 & 1.000 & Fix & Valid & 1.000 & \multirow{3}{*}{$\begin{array}{c}0.727 \\
\text { Reliabel }\end{array}$} \\
\hline Y1.2 & 1.150 & 0 & Valid & Valid & \\
\hline $\mathrm{Y} 1.3$ & 0.783 & 0 & Valid & Unidimensiona & \\
\hline
\end{tabular}

Source: Processed SEM Results

The results of the validity and reliability test of the instruments in Table 8 show that the research instrument for the variable Regional Revenue and Expenditure Factors (APBD) with indicators of regional own-source revenue (Y.1.1), balancing fund indicators (Y.1.2), and regional loan indicators (Y1.3) is valid and reliable.

Table 9. Test results of the validity and reliability of research instruments for the Revenue Sharing variable

\begin{tabular}{|c|c|c|c|c|c|}
\hline \multirow{2}{*}{ Indicator } & \multicolumn{4}{|c|}{ Validity Test } & $\begin{array}{c}\text { Constract } \\
\text { Reliability }\left(\boldsymbol{\rho}_{\Pi}\right)\end{array}$ \\
\cline { 2 - 5 } & Estimate & $\mathbf{P}$ & $\begin{array}{c}\text { Informatio } \\
\mathbf{n}\end{array}$ & GFI & \\
\hline Y2.1 & 1.000 & $\mathrm{Fi}$ & Valid & 1.000 & \multirow{2}{*}{$\begin{array}{c}0.704 \\
\text { Reliabel }\end{array}$} \\
\hline Y2.2 & 0.824 & 0 & Valid & Valid & \\
\hline Y2.3 & 0.998 & 0 & Valid & $\begin{array}{c}\text { Unidimensiona } \\
1\end{array}$ & \\
\hline
\end{tabular}

Source: processed SEM Results

The results of the validity and reliability test of the instruments in Table 9 show that the research instrument for the profit sharing variable is valid and reliable.

\section{Test Assumptions Underlying SEM Data Outliers Test}

Inspection of data outliers is done by the Mahalanobis distance method. If the Mahalanobis distance is significant ( $\mathrm{p}<0.05)$, then the data is said to be outliers. Tests performed in conjunction with SEM analysis using the software AMOS 4:01. The results of the examination using Mahalanobis distance show that statistically there are several observations that are outliers. Given the results of descriptive analysis which shows that all indicators have a minimum value of 1 and a maximum of 5 that is within the specified score limit, the observed data that the outliers are not discarded. 


\section{Data Normality Test}

Multivariate normality distribution testing is performed using AMOS 4.01 software. The results show that multivariate data are not normally distributed ( $\mathrm{cr}=24,126$; Critical $\mathrm{Z}$ value for $\alpha=0.05$ is 1.96 ; if $\mathrm{cr}>\mathrm{Z}$ is Critical then it is not normally distributed). Referring to the central limit theorem (limit central theorem) when the sample size gets bigger, the statistics obtained will approach the normal distribution. The number of units of analysis in this study, namely $n=131$, is considered to have fulfilled the central limit proposition so that the assumption of normality can be ignored.

\section{Linearity Test}

Testing linearity assumptions using the Curve Fit method performed with SPSS 14.0 software. The reference used here is the parsimony principle which is when all the models used as a basis for testing significant or non-significant means the model is said to be linear, quadratic, cubic, inverse, logarithmic, power, S, compound, growth and exponential.

\section{Test Goodness of Fit Model Early Phase SEM Analysis Results.}

The theoretical model in the conceptual framework of the study, said to be fit if it is supported by empirical data. To find out whether the hypothetical model is supported by empirical data or not, atested goodness of fit overall model is.

Testing the structural equation to see the effect of the fiscal system and cost recovery on the APBN, APBD and Revenue Sharing is carried out using the structural equation model with the help of the AMOS 4.01 program.

The description of the resultstesting ofgoodness of fit overall model the initial stageas presented in Table 10 below:

Table 10. Testing the Goodness of Fit Overall Model Early Stage

\begin{tabular}{|c|c|c|c|}
\hline $\begin{array}{c}\text { Goodness of } \\
\text { Fit }\end{array}$ & $\begin{array}{c}\text { Calculation } \\
\text { Results }\end{array}$ & $\begin{array}{c}\text { Cut- } \\
\text { Off }\end{array}$ & Information \\
\hline Chi Squared & 172.725 & small & \\
\hline P & 0.0000 & $>0.05$ & Bad model \\
\hline RMR & 0.034 & small & \\
\hline RMSEA & 0.066 & $\leq 0.08$ & Good model \\
\hline GFI & 0.867 & $\geq 0.90$ & Bad model \\
\hline AGFI & 0.815 & $\geq 0.90$ & Bad model \\
\hline CFI & 0.923 & $\geq 0.94$ & Bad model \\
\hline Chi Squared/df & 1.570 & $\leq 2$ & Good model \\
\hline
\end{tabular}

\section{Source: Prosessed SEM Result}

Table 10 shows that the goodness of fit test, especially Chi Square with P-value = 0,000 , thus the model is said to be ugly. Based on modification indices, modifications are made to improve the model. Modification of the model is done by connecting between variables or errors and by not modifying the path of influence.

\section{Final Stage SEM Analysis Results}

Table above shows that the p-value and Chi Square test are greater and $\alpha=0.05$, so the hypothetical model is supported by empirical data or the model can be said to be good. 
Likewise with other fit size values such as RMSEA, GFI, CFI and Chi Square Pdf shows the model can be said to be good.

Confirmatory factor analysis of the final results which is additional to see the relationship between revenue sharing funds (Y2) and APBD (Y1), after disposal of oil and gas taxation system indicators (X1.4) is as described in the following:

Table 11.Testing Goodness of Fit Overall Model Final Stage

\begin{tabular}{|c|c|c|c|}
\hline Goodness of Fit & $\begin{array}{c}\text { Calculation } \\
\text { result }\end{array}$ & $\begin{array}{c}\text { Cut- } \\
\text { Off }\end{array}$ & Information \\
\hline Chi Squared & 110.479 & Kecil & \\
\hline P & 0.223 & $>0.05$ & Good model \\
\hline RMR & 0.029 & Kecil & \\
\hline RMSEA & 0.028 & $\leq 0.08$ & Good model \\
\hline GFI & 0.916 & $\geq 0.90$ & Good model \\
\hline AGFI & 0.871 & $\geq 0.90$ & $\begin{array}{c}\text { Marginal } \\
\text { model }\end{array}$ \\
\hline CFI & 0.987 & $\geq 0.94$ & Good model \\
\hline Chi Squared/df & 1.105 & $\leq 2$ & Good model \\
\hline
\end{tabular}

Table 11 shows that the p-value and Chi Square test are greater and $\alpha=0.05$. so the hypothetical model is supported by empink data. or the model can be said to be good. Likewise with other fit size values such as RMSEA. GFI, CFI and Chi Square / $\mathrm{df}$ indicate the model can be said to be good.

\section{FINDINGS AND DISCUSSION Revenue Sharing Fund (Y.2)}

One of the APBN contributions submitted to the regions is revenue derived from Oil and Gas Revenue Sharing Funds which have been calculated in such a way based on the total volume of the structure multiplied by the total production of the mining working area.

The Ministry of Finance, especially the Directorate General of Central and Regional Financial Development, is only tasked with collecting data and not losing data. Calculation of natural resources revenue sharing is carried out by the technical department concerned except for oil and natural gas which is a collaboration between the Department of Energy and Mineral Resources and the Ministry of Finance (Mahfud, S., 2002: 134).

Profit sharing and oil mining funds as referred to in 14 letter e number 2 in the amount of $15 \%$ (fifteen percent) are divided by the following details:

- $3 \%$ (three percent) is distributed to the province concerned.

- $6 \%$ (six percent) distributed to producing districts / cities; and

- $6 \%$ (six percent) to other districts / cities in the province concerned.

Revenue from natural gas mining produced and the relevant regional area after deducting the components of taxes and other levies in accordance with statutory regulations, divided by the balance;

- $69.5 \%$ (sixty nine and a half percent) for the Government: and

- $30.5 \%$ (thirteen and a half percent) for the regions. 
- Revenue sharing and natural gas mining as referred to in Article 14 letter $\mathrm{f}$ number 2 in the amount of $30 \%$ (league twenty percent) is divided by the following details:

- $6 \%$ (six percent) is distributed to the province concerned.

- $12 \%$ (twelve percent) distributed to producing districts / cities; and.

- $12 \%$ (twelve percent) is distributed to other regencies / cities in the province concerned.

In accordance with Article 7 of Law No. 33 of 2004 that to allocate DAU a formula is used which formulates the basic variables stipulated in the Act referred to, which is based on estimates of regional financing needs and regional economic potential, in this case the potential revenue of the region concerned. This is in line with the concept of calculating a fiscal gap based on financing fiscal needs and fiscal capacity (Machfud 5., 2002: 95).

If we consider what was revealed by Richardson, W., that the regional analysis approach can be called interregional macroeconomics, this is the application of the national income model and the national growth model to the regional level, although it must be noted that each the region is also treated as an open economy and thus these models determine trade and interregional factor flows and also regional income (Sanusi, B., 2002: 79).

The income of an area depends on the available natural resources, the technology that is processed so that it becomes an goods of production and innovative human resources so that these natural resources can become economic goods for management, a decentralization policy is needed.

One of the old doctrines in determining the right source of income for each level of the government hierarchy is what is known as the doctrine of revenue sources. The purpose of decentralization is to improve the efficiency of public services for all members of the community that spreads throughout the country. Each place has its own specifications, which require different public service contents, bound to what is called human and resources local.

Revenue-sharing funds are funds provided to increase regional income in the context of financing the implementation of functions which become the authority carried out with a pattern of revenue sharing from tax and non-tax (SDA) revenue between the center and the regions. In accordance with Law No. 33 of 2004, the revenue sharing pattern is carried out with a certain percentage based on the region of origin (by origin).

The revenue sharing from the state includes revenue from land and building tax, land and building acquisition tax (BPHTB), and natural resource revenue sharing (SDA) consisting of the forestry sector, general mining, oil and natural gas, and fisheries. The revenue sharing is to the regions with a certain percentage regulated in Law Number 33 of 2004 and PP Number 104 of 2000 concerning equalization funds as amended by PP Number 84 of 2001.

Netzer on Simarmata Dj.A 1994: 210 gives three arguments on the mechanism Intergovernmental namely:

Buchanan's argument for justice which demands that on the basis of consideration of geographical differences in income and wealth, the central government is responsible for equalization efforts. This can be termed an equalization budget. 
Fiscal imbalance or fiscal inequality argues that the allocation of expenditure responsibilities between levels of government should be based on the principle of economies of scale. On the basis of observing the data, it was concluded that many public services were included in the constant scale economic activity group. This means that many aspects of expenditure must go to the local government or the lowest level of government, in areas where internal profits are the largest. This means that decentralization is getting lower in the hierarchy of government. On the other hand, the other side which concerns income collection, or in the sense of the cost of tax collection, has different levels of government conclusions. The principle of scale economics and the revenue side generally requires a higher level of government hierarchy than the expenditure side demands. This is the basis of the previous statement that the same level of government coincidence for revenues and expenditures for one particular program is very small. This conclusion, which was obtained from a theoretical and practical analysis, led to an imbalance between revenues and expenditures for one BKU program at each level, with general tendencies; the amount of revenue at one level of the highest hierarchy and maybe so at the next level is greater than the expenditure responsibility. So the principle of fiscal imbalance arises from different economic justifications at each level of government in the collection of costs and expenses, which are caused by the existence of external geographical effects of each government program, or every provision of BKU.

The third argument is that unconditional grants are based on equity and also return externalities. If from the point of view of the national interest it is desirable to spread economic activities and equitable distribution of income and wealth in all national spaces, while an accurate calculation of external impacts cannot be carried out, then the granting of unconditional grants is one of the recommended instruments. But this method should be used as a temporary effort, which should be completed later, if the problem of the magnitude of the BKU's impact can have an external impact and equity, then the unconditional grant instrument within the BKU will be more specifically determined.

\section{Regional Revenue and Expenditure Budget (Y.1)}

The government's determination to increase the role of regional governments in managing their own regions is reinforced by the birth of the Regional Autonomy Law which consists of Law of the Republic of Indonesia No. 22 of 1999 concerning Regional Government and Law of the Republic of Indonesia No. 33 of 2004 concerning Financial Balance between Central and Regional Governments.

Prior to the enactment of Law No. 33/2004, the statutory regulations governing the financial balance between the central and regional governments were Law No. 32/1956 concerning Fiscal Balance between the State and Regions which had the right to manage their own households. This law stipulates among other things the regional financial sources as follows:

1. Sources of original regional revenue, consisting of local taxes, regional levies, and the results of regional companies. The eight types of central taxes are submitted to the regions to become local taxes, namely the verponding tax, Indonesian verponding tax, household tax, motor vehicle tax, road tax, animal slaughter tax, copra tax and Development Tax I.

2. Most (of a certain percentage) from the collection of certain state taxes, import duties, export duties, and customs duties are left to the regions. Certain state taxes are 
transitional tax, wage tax, stamp tax, wealth tax and company tax. The portion of the central revenue for this region is totaled together into one revenue group and then distributed to the regions based on factors, namely: I) Area of Area; II) Total population; III) Economic potential; IV) Level of intelligence; V) Expensiveness The length of the roads managed by the area; VI) The length of irrigation canals that are managed by the region; VII) What is the area in whole or in part consisting of islands.

3. Rewards for subsidies and assistance given to regions in certain cases. It turned out that the implementation of this Law had difficulties, especially in applying the state tax revenue sharing system (item $b$ above). The distribution of financial resources to regions based on these eight factors is difficult to calculate, while the data needed to calculate them is also difficult to obtain on time. (Doli D Siregar 2004; 300)

To overcome these difficulties, from 1956 to the fiscal year 1999/2000 financial balance between Central and Regional Governments are based on various ad hoc government policies.

Republic of Indonesia Law No. 22 of 1999 concerning Regional Government and Law of the Republic of Indonesia No. 33 of 2004 concerning Fiscal Balance between the Central and Regional Governments is thus ready for the government system in Indonesia to implement a government system that places the role of the regional government in a very crucial position in improving the welfare of its citizens. The role of taxes and levies as the main source of local revenue in addition to the balance funds obtained from the exploration of natural resources will greatly determine the strength of the APBD (M. Suparmoko 2002: 111).

One of the effects of regional autonomy and fiscal decentralization is the need to reform local financial management (Mardiasmo 2002; 140).

Doli D Siregar $(2004 ; 304)$ "Various empirical studies prove that decentralization has not only failed to improve public sector services at the local level but has even resulted in the risk of national instability in the political, social and economic fields". The greatest risk is when the main source of government revenue is handed over to the regional government without following policy measures that guarantee the mobilization of regional revenue to finance various public services that are the responsibility of the local government. Theoretically, the policy regarding financial relations between the central and regional governments can basically be seen from 3 (three) aspects, namely:

1. It is an effort to bring together financial sources / financing with the tasks, responsibilities, and functions of the government charged to the regions.

2. Is the allocation / reallocation of financial resources between the central and regional governments.

3. Is a way of financing for an autonomous public legal entity with various types of funding sources, such as regional taxation, balance funds and so on (D Siregar, 2004: 307).

In the implementation of fiscal decentralization, sources of regional revenue are based on Law No. 25 of 99 concerning Financial balance between Central and Regional Governments can be seen in the Figure as follows : 


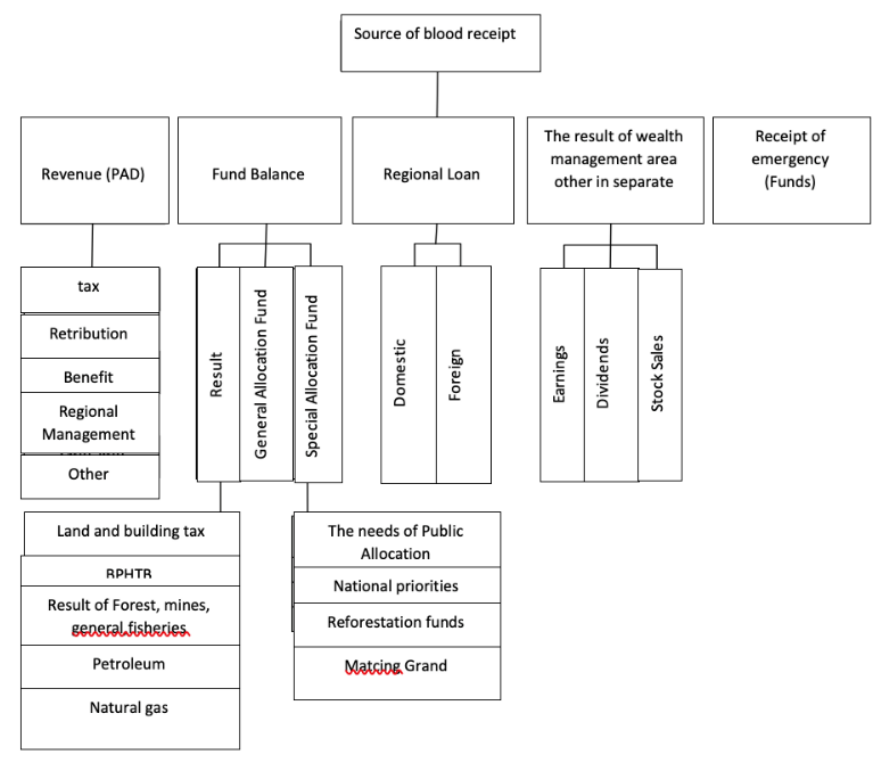

Figure 2. Sources of Regional Revenue

\section{Regional Original Income (Y.1.1)}

Income Regional Originalis revenue received by the Region from sources within its own region which is levied based on Regional Regulations in accordance with applicable laws and regulations.

Sources of Original Regional Revenue as referred to in article 3 letter a of Law Number 33 of 2004 concerning Financial Balance between Central and Regional Governments shall consist of:

a. Regional tax proceeds

b. Regional retribution results

c. results of regionally owned companies and results of management of other separated regional assets.

d. other valid Local Original Revenue.

\section{Balancing Fund (Y.1.2)}

Financial balance between the center and the regions is a system of government financing within the framework of a unitary state, which includes financial sharing between the central and regional governments and proportional, democratic, fair and transparent distribution of regions taking into account the potential, conditions and regional needs, in line with the obligations and distribution of authority as well as the procedures for the implementation of such authority, including the management and financial supervision. (Doli D Siregar, 2004: 305).

From the definition of the central and regional financial developments it containsdesirable a fairly broad range of understandings, namely:

1. That in the implementation of regional autonomy it isto realize a form of horizontal and vertical justice. 
2. Trying to realize a better governance arrangement (from the financial side) towards the realization of clean government and good governance.

This central and regional financial balance is the main tool in the implementation of fiscal decentralization, as a consequence and the implementation of regional autonomy. The full fiscal decentralization implies that in order to support the implementation of regional autonomy vast, realistic and responsible, the area is given:

The authority to utilize the financial resources of its own and is backed by financial equilibrium between the central and local (Doli D Siregar (2004: 306) words other balancing funds are contributions from the State Budget (APBN) to the Regional budget.

This Balancing Fund consists of:

1. Regional portion of revenue from land and building tax, acquisition fees for land and building rights and revenue from natural resources.

2. General Allocation Funds.

3. Special Allocation Funds

\section{Regional Loans (Y, 1.3)}

Law Number 33 of 2004 concerning Financial Balance between Central and Regional Governments (PKPD) stipulates that regional loans are one of the sources of regional revenue in the context of decentralization, which are recorded and managed in the Revenue Budget and Regional Expenditure (APBD).

Loan funds are a complement to existing regional revenue sources and are intended to finance the procurement of regional infrastructure or other fixed assets related to activities that are increasing revenues that can be used to repay loans, as well as providing benefits to community services.

Regional loans need to be adjusted to the capacity of the region, because it can create a burden for the Regional Budget and Revenues (APBD) in the following years which are quite heavy so it needs to be supported by the skills of regional apparatus in managing regional loans.

\section{The Effect of Revenue Sharing Funds (Y.2) on APBD (Y.1) Revenue}

The results of the analysis show thatSharing significantly influence the APBD is accepted. Standardize path coefficient $=0.389$ with P-value $=0.084$, thus decided significant. This shows that the positive effect of revenue sharing funds on the positive regional budget is significant. The higher the proportion of revenue sharing funds, the higher the revenue for APBD sourced from revenue sharing funds for producing regions.

The effective implementation of fiscal decentralization took effect on January 1, 2001 in accordance with Law Number 22 of 1999 and Law Number 33 of 2004 concerning Central and Regional Financial Balances. In accordance with the two laws, in the context of implementing fiscal decentralization, the regions are given the authority to utilize their own financial resources and are supported by financial balance between the center and the regions (Jane, 0 .. 2002: 72). 
Inline with the division of authority, the regional financing arrangements are based on the principle of government administration. Financing of government administration based on the principle of decentralization is carried out at the expense of the APBD, financing of government administration in the framework of implementing the principle of deconcentration is carried out at the expense of the APBN and financing of government administration in the framework of co-administration is financed on the level of the government budget that it assigns (Jane, 0., 2002: 74).

The results showed that the revenue sharing fund greatly affected the APBD revenue from the producing regions, because the greater the portion of the allocation of balance funds originating from oil and gas natural resources, the greater the portion of producing regions.

This Revenue Sharing Fund gives the biggest contribution to the APBD of the region producing.

\section{CONCLUSIONS}

Revenue sharing has a significant effect on the APBD of the Oil and Gas Producing Regions. This shows that the positive influence of oil and gas revenue sharing funds on the Regional Oil and Gas Producing Regional Budgets is significantly positive. The higher the portion of the allocation of revenue-sharing funds, the higher the revenue for Regional Oil and Gas Producing Regional Budgets originating from revenue-sharing funds for producing regions. With the increase in the APBD of the Oil and Gas Producing Regions, the prosperity of the producing regions is expected to increase due to a balanced and equitable accounting mechanism.

\section{RECOMMENDATIONS}

1) In preparing the fiscal system for oil and gas sector cooperation contracts, regional aspirations regarding royalties or lease interest should be considered in the cooperation contract clause, so that producing regions feel they have a business in the oil and gas sector.

2) To the Central Government in this case the Ministry of Energy and Mineral Resources, the Ministry of Finance and BP MIGAS in calculating the allocation of revenue-sharing funds should use a standard and transparent allocation formula and involve producing regions.

3) To the Central Government in this case the Department of Energy and Mineral Resources and BP MIGAS should deliver the production produced by each producing region based on production or lifting reports that actually occur quarterly to the producing regions.

\section{REFERENCE}

Asmawi. (2008, April 22). Price of oil and gas, Riau Pos, p. 1.

Barata, A.A. dan B.Trihartono, 2004, Kekuasaan Pengelolaan Keuangan Negara/Daerah, ISBN 234040883, Gramedia, Jakarta.

Oetomo. (2004, October 21). Standard Price of oil and gas, Kompas, p. 6. 
Johnston, D. 1994, International Petroleum Fiscal Systems and Production Sharing Contracts, ISBN 0-87814-426-9, PennWell Publishing Company, Tulsa.p.51

Julianti. W, 2002, Share Fund Material Seminar, ESDM, Jakarta. p.3.

Patowidagdo, W, 2002, Manajemen dan Ekonomi Minyak dan Gas Bumi, ISBN 979-957462-5, Program Studi Pembangunan PPS ITB, Bandung. P.80

Rezky Sri Wibowo, 2005, Transparansi Ekonomi Ekstraktif Di Indonesia, Journal Transparency International Indonesia, Jakarta p.65

Sutadi P.U, 2002, PSC Contractual System Course, LDI Training, Yogyakarta.

Sugiyono, 2001, Metodo;ogi Penelitian, AlfaBeta, Bandung.

Bird, R.M. and V. Francois, 2000, Fiscal Decentralization in Developing Countries, ISBN 979-655-823-8, AJih Bahasa AJmizan UWa, Gramedia Pustaka Utama, Jakarta.

Sanusi, B. 2002, Perenan Migas dalam Perekonomian Indonesia, ISBN 979-8398-46-7, PenerM Univers a s Trisakti, Jakarta.

- - - 2004, PoIensi Ekonomi Migas Indonesia, ISBN 979-518-872-0, Rineka Cipla, Jakarta.

Siregar, D. D. 2004, Manajemen Aset, ISBN 979-22-0761•9, Gramedia Pustaka Ulama, Jakarta.

Sidik, Machfud. and B.R.Mahi, 2002, Dana Alokasi Umum, Konsep Hambatan dan Prospek di Era otonomi Daerah, ISBN 979-709-048-5, Penerbil Buku Kompas, Jakarta.

Patowidagdo, W, 2002, Manajemen den Ekonomi Minyak dan Gas Bumi, ISBN $97995746-$ $2 \bullet 5$, Program Studi Pembangunan PPS ITB, Bandung.

- - -- , 2004, Mengenal Pembengunan dan Ana/isis Kebijakan, ISBN 979•95746-Q..9, Program Studi Pembangunan PPS ITB, Bandung

Suparmoko, M, 1997, Ekonomi Sumberdaya Alam dan Lingkungan, ISBN 979-503--305•0, BPFE•Yogyakarta, Yogyakarta.

----- " 2002, Ekonomi Pubfik, ISBN 979•533--792-0, ANDI Offset, Yogyakarta.

Djojohadikusumo. S. 1994, Dasar Teori Ekonomi Peltumbuhan dan Ekonomi Pembangunan, ISBN 979-8391•26-6, Pustaka LP3ES Indonesia, Jakarta. 